\title{
Globally Networked Learning in a University Classroom: A Pilot Program
}

\author{
By Steven M. Oberhelman* \\ Christina A. Dunn ${ }^{\dagger}$
}

In 2017, the College of Liberal Arts at Texas A\&M University created an initiative modeled on the State University of New York's Collaborative Online International Learning (COIL) program. COIL is an approach to fostering global competence through the development of a multicultural learning environment that links university classes in two different countries. Using various communication technologies, students complete shared assignments and projects, with faculty members from each country co-teaching and managing coursework. We piloted a COIL program with the purpose of fostering global competence and a multicultural learning environment through linking a Texas A\&M Liberal Arts class and a university class in a foreign country. Each of the paired classes met separately and regularly in its home country for much of the semester, but the students also worked asynchronously online to share ideas, collaboratively produce work relevant to the course of study, and reflect upon their own and their partners' cultural points of view. In this paper we discuss the results of this pilot program.

Keywords: global learning, online learning, internationalization, study abroad, student success

\section{Introduction}

It is a well-known fact that study abroad brings tremendous benefits to students. Three academic advantages may be quickly singled out. First, students who participate in a study abroad program display better overall academic achievement. Research shows slightly higher four-year graduation rates for students who studied abroad to those who did not. ${ }^{1}$

Second, students who engage in an overseas experience also stay in college.

\footnotetext{
*Associate Dean of Undergraduate Studies Professor of Classics, George Sumey, Jr. Professor of Liberal Arts, Texas A\&M University, USA.

${ }^{\dagger}$ International Programs Manager, College of Liberal Arts, Texas A\&M University, USA.

${ }^{1}$ This is the conclusion of many tier 1 research universities, such as University of California, Berkeley (https://opa.berkeley.edu/sites/default/files/studyabroad_finalterm_17may2017.pdf), and Colorado State (http://irpe-reports.colostate.edu/pdf/ResearchBriefs/EA_Graduation_Ra tes.pdf). Review of the evidence in Barclay, 2011, with the most recent evaluation in Haupt, Ogden, \& Rubin, 2018. Malmgren \& Galvin, 2008 discuss how study abroad improves graduation rates for atrisk students and students of underrepresented groups. The webpage http://globaledresearch. com/study-abroad-impact.asp lists 20 studies (with links) for reports by universities examining the effect of study abroad on graduation, retention, and learning. The higher GPRs earned by Texas A\&M students who have international experiences may not necessarily be directly attributable to time abroad. At Texas A\&M, no student with a GPR below 2.0 is eligible for study abroad; the same prohibition applies to students on academic probation. Thus, sudy abroad students are already achieving higher grades from the onset; their final GPR at graduation may be more a reflection of their overall academic abilities than the result of the academic skill-sets acquired from education abroad.
} 
Retention is as critical for accountability in higher education and for state legislatures as graduation rates (Tinto, 1987). ${ }^{2}$ At Texas A\&M the difference in retention rates for students who stay on campus and students who study overseas is about $10 \%{ }^{3}$ Given Texas A\&M's annual freshman class of 10,000, if all students were afforded some type of international experience, this would result in the retention of about 750 students.

Third, employers value study abroad experiences. Students who have studied abroad find that they have an advantage on the job market, especially when they are able to articulate in interviews the connection between their overseas experiences and job skills.

In recent surveys, employers have identified the study abroad skill-sets that they consider highly desirable in potential employees: cross-cultural communications skills, autonomy and independence, leadership skills, innovation, maturity, cultural awareness, and flexibility (Deardorff, 2004; Hunter, 2004; Fukai, 2016). In today's global economy and a highly diverse workforce, study abroad gives students a wider perspective of the world, the ability to work in a diverse environment, the means to adapt to change, open-mindedness, and a basic knowledge of the world outside a limited view. ${ }^{4}$

Despite the advantages to study abroad, in the United States only $10 \%$ of undergraduates will have abroad upon graduation (Institute for International Education, 2018). While it is important to increase study abroad participation, an equally critical question may be how to internationalize students who choose to remain on campus. In this article, we first discuss the misconceptions about study abroad and what barriers exist for students. Then, we describe a new program that we piloted in our college to give students an opportunity for interactive, highimpact international experiences without ever leaving their campus. Finally, we present the results of the pilot program.

\section{Misconceptions about Study Abroad}

In recognition of the great benefits of international experiences to students, academically, personally, and professionally, Texas A\&M University has been very proactive in emphasizing study abroad. It is currently second in the nation for the number of students who study abroad, and is eclipsed only by New York University. ${ }^{5}$ In the 2016-2017 academic year, Texas A\&M sent 5,539 students

\footnotetext{
${ }^{2}$ The academic journal, The Journal of College Student Retention: Research, Theory \& Practice, has offered since 1999 three issues a year dealing with the subject.

${ }^{3}$ Specific data for Texas A\&M University students (university-wide and college-wide) are available by emailing us at s-oberhelman@tamu.edu or cadunn@tamu.edu.

${ }^{4}$ Students themselves acknowledge the value of the acquisition of global competence and workplace skills through their international experiences. Students are administered the Global Perspective Inventory (GPI) survey before they undertake an overseas experience and then again after it. The GPI is a web-based survey that assesses an individual's development of global perspectives. For the GPI and its application, see Braskamp, 2014 and Braskamp, Braskamp, \& Engberg, 2014.

${ }^{5}$ As determned by the Institute for International Education (2018). Because New York University is a private university, this places Texas A\&M at the top of public universities. For national data and discussion of them, see the State Department's report at https:// studyabroad.state.gov/value-study-
} 
overseas (Table 1).

Table 1. Number of Students with Overseas Experiences by College at Texas A\&M University

\begin{tabular}{|l|c|c|c|c|c|}
\hline College & $\mathbf{1 2 - 1 3}$ & $\mathbf{1 3 - 1 4}$ & $\mathbf{1 4 - 1 5}$ & $\mathbf{1 5 - 1 6}$ & $\mathbf{1 6 - 1 7}$ \\
\hline Agriculture and Life Sciences & 390 & 503 & 534 & 601 & 618 \\
\hline Architecture & 214 & 264 & 231 & 306 & 407 \\
\hline Bush School of Government \& Public Service & 59 & 37 & 46 & 75 & 51 \\
\hline Education and Human Development & 239 & 526 & 452 & 491 & 477 \\
\hline Engineering & 591 & 601 & 732 & 1,032 & 963 \\
\hline Galveston Campus & 68 & 237 & 326 & 431 & 464 \\
\hline Geosciences & 83 & 92 & 128 & 185 & 129 \\
\hline Health Science Center & 15 & 16 & 42 & 13 & 122 \\
\hline Liberal Arts & 890 & 934 & 965 & 881 & 971 \\
\hline Mays Business School & 423 & 518 & 584 & 627 & 636 \\
\hline Qatar Campus & & 157 & 210 & 223 & 218 \\
\hline School of Law & & 11 & 10 & 29 & 47 \\
\hline Science & 144 & 149 & 154 & 145 & 139 \\
\hline Transition Academic Programs* & 69 & 24 & 40 & 40 & 36 \\
\hline Unknown & 6 & 2 & 8 & & \\
\hline Veterinary Medicine and Biomedical Sciences & 136 & 159 & 203 & 251 & 261 \\
\hline TOTAL & $\mathbf{3 , 3 2 7}$ & $\mathbf{4 , 2 3 0}$ & $\mathbf{4 , 6 6 5}$ & $\mathbf{5 , 3 3 0}$ & $\mathbf{5 , 5 3 9}$ \\
\hline
\end{tabular}

When students go overseas, it is for many reasons: academic course work, research, field trips, and internships. At Texas A\&M, the most popular is the faculty-led study abroad program, which vary from five weeks to one semester in length, or field trips, typically one week in length and embedded in a campusbased course; nearly $70 \%$ of students participated in one of these two experiences (Table 2). ${ }^{6}$

Table 2. Types of Overseas Experiences for Texas A\&M Students

\begin{tabular}{|l|c|c|c|c|c|}
\hline Program Type & $\mathbf{1 2 - 1 3}$ & $\mathbf{1 3 - 1 4}$ & $\mathbf{1 4 - 1 5}$ & $\mathbf{1 5 - 1 6}$ & $\mathbf{1 6 - 1 7}$ \\
\hline Conference/Workshop/Training & 203 & 304 & 383 & 426 & 511 \\
\hline Exchange Programs* & 159 & 187 & 266 & 346 & 226 \\
\hline Faculty-Led & 1,091 & 1,240 & 1,278 & 1,949 & 1,998 \\
\hline Internship** & 136 & 189 & 139 & 174 & 176 \\
\hline Research & 230 & 404 & 469 & 257 & 263 \\
\hline Service Learning/Volunteer & 40 & 23 & 34 & 36 & 71 \\
\hline Short Term Group Trip & 1,043 & 1,367 & 1,572 & 1,637 & 1,742 \\
\hline Study*** Courses not for credit) & & 19 & 30 & 13 & 50 \\
\hline Supervised Direct Enrollment & 30 & 37 & 39 & 67 & 86 \\
\hline Teach Abroad*** & 2 & 1 & 8 & 16 & 12 \\
\hline Transfer Credit Study Abroad & 393 & 459 & 447 & 409 & 404 \\
\hline Grand Total & 3,327 & 4,230 & 4,665 & 5,330 & 5,539 \\
\hline
\end{tabular}

abroad/study-abroad-data.

${ }^{6}$ Houser, Brannstrom, Quiring, \& Lemmons, 2011 discuss the benefits of field trips; also Peet, Wooldridge, \& Sturm, 2015. Simoes, 1996 notes the significant gains associated with short-term study abroad and not necessarily longer study abroad programs. 
Although the benefits of study abroad are well-known to administrators, employers, and faculty, there is still some hesitation among students and parents or legal guardians. Several factors are at play, most significantly cost (Gordon, Patterson, \& Cherry, 2014).

Study abroad if often perceived to cost far more than staying on a home campus. But the data do not support this; in fact, the costs of overseas study in many instances are comparable to on-campus study. As a test case, let us look at a long semester (15 weeks) in College Station and an equivalent semester at the Texas A\&M Study Center in Castiglion Fiorentino, a Tuscan town 95 kilometers south of Florence.

First the costs for a student studying on the College Station campus in the fall of 2018 is shown in Table 3.

Table 3. Costs for Spring 2018 Semester, College Station

\begin{tabular}{|l|c|}
\hline Costs & Resident $\mathbf{( \$ )}$ \\
\hline Tuition \& Fees (15 hours) & 5,142 \\
\hline Loan Fees & 32 \\
\hline Housing \& Meals & 5,218 \\
\hline Books \& Supplies & 700 \\
\hline Travel & 2,400 \\
\hline Personal Expenses & 3,500 \\
\hline Total & 16,922 \\
\hline
\end{tabular}

The costs of 15 hours at the Castiglion Fiorentino Study are outlined in Table 4.

Table 4. Costs to Study Abroad in Italy, Spring, 2018

\begin{tabular}{|l|c|}
\hline Costs & Resident $\mathbf{( \$ )}$ \\
\hline Tuition \& Fees (15 hours) & $\$ 5,142$ \\
\hline Loan Fees & 32 \\
\hline Housing \& Meals & 6,600 \\
\hline Books \& Supplies & 250 \\
\hline Travel & $3,000^{7}$ \\
\hline Personal Expenses & $2,000-6,000^{8}$ \\
\hline Total & $14,024-18,024$ \\
\hline
\end{tabular}

As we read in Tables 3 and 4, the difference in costs between on-campus study and a semester in Tuscany are negligible. There are additional costs for overseas study, but these are attributable to personal travel, gift purchases, and extra meals, not programmatic costs. Not all study abroad programs, however, take place in a medieval Tuscan town like Castiglion Fiorentino where the cost of living is low. The costs may be higher for programs in London, Paris, Tokyo, or

\footnotetext{
${ }^{7}$ Both personal travel and academic travel, including airfare, are combined.

${ }^{8}$ The range is considerable, depending on the student. Students are allowed a free weekend every other week. Some students take every advantage to travel, while others travel only moderately or stay close by, say, in Florence.
} 
Berlin. 9

The cost of higher education is increasingly on the minds of students. Reports show that two-thirds of college students are "food insecure," that is, they have limited adequate food, and about half are "housing insecure," that is, either they must often move because of the inability to pay rent or they cannot afford decent housing (Goldrick-Rab, Richardson, \& Hernandez, 2017; Goldrick-Rab, Richardson, Schneider, Hernandez, \& Cady, 2018 for data and discussion as well bibliography; Maroto, Snelling, \& Linck, 2015 on food insecurity and its effect on academic performance by college students). Given the declining impact of financial aid, coupled with lost wages from time away, it is no surprise that many students perceive study abroad as unaffordable (Greenbaum, 2012; Goldrick-Rab, 2016; Gordon, Patterson, \& Cherry, 2014).

These misperceptions disproportionately impact low-income students, who are more likely to be first-generation or minoritized, and thus underrepresented in study abroad. Also an increasing number of undocumented university students, mostly from Mexico and Central America, are enrolled at Texas A\&M. However, they cannot leave the United States because they do not possess the proper papers. ${ }^{10}$

As observed at Texas A\&M, some students do not want to miss out on extracurricular activities. This is especially true when American football season is in full swing and the campus has events the entire weekend, from Friday night gatherings through Sunday tailgating. Even the spring has its own extracurricular attractions. The upshot is that some students simply wish to stay home and enjoy an on-campus experience.

Another significant barrier to student participation is lack of family support (Gordon, Patterson, \& Cherry, 2014). Familial expectations and parental perceptions of travel or safety abroad can influence students' decisions. The majority of Texas A\&M students prefer participate in programs based in northern European destinations like England, France, and Germany. Every terrorist incident has a negative impact on the perception of safety abroad (Baker, 2014 on terrorism's role in discouraging travel; Gleye, 2017 for a first-hand account of students experiencing firsthand terror attacks).

\section{Collaborative Online International Learning}

In recognition of impediments to study abroad, and to expand the types of international experiences that are made available to students, we turned to the development and implementation of collaborative international courses. "Collaborative Online International Learning," or COIL, is a pedagogy that is

\footnotetext{
${ }^{9}$ Every university has a study abroad office that can assist students in finding the right program at the right price. The Internet can help interested students; there are numerous sites for guesstimates for studying abroad; for example, https://www.gooverseas.com/blog/how-much-does-it-cost-tostudy-abroad.

${ }^{10}$ Study abroad is possible through the Department of Homeland Security's Deferred Action for Childhood Arrivals or DACA. The problem is that undocumented students cannot receive any federally funded student financial aid, and so they cannot use federal loans, grants, and scholarships.
} 
international and yet also interactive and virtual. COIL may also be defined as globally networked learning. The term COIL was coined by the State University of New York, which is a pioneer in this field and has inspired not only our pilot program but those at many other institutions. ${ }^{11}$ In COIL courses, students from two countries use different communication technologies to work on common assignments or to complete collaborative projects. Faculty in each country work with their own students but also work closely with each other. ${ }^{12}$

A COIL course typically has certain characteristics. ${ }^{13}$ First, the two instructors work out the course curriculum ahead of time, paying close attention to logistics. The students at the two institutions work together for about four weeks; some COIL courses involve semester-long work, although three or four weeks are the average. Students must work in collaboration on assignments or problems; they can be paired or form small groups. The interaction between students is conducted through technology; the platforms that are used are at the discretion of the instructors and are dependent on what technology is available at the institutions and to students. Video-conferencing platforms like Skype and Google hangouts, networks like Facebook, and document-sharing programs like Google Docs allow students to communicate easily and quickly. ${ }^{14}$ Students are enrolled at own institution and their work is assessed by the home instructor. In other words, a student has a meaningful, intense, and high-impact international learning experience without ever leaving their campus.

In January of 2017 at Texas A\&M, we issued, as part of a pilot program, a call to faculty in the College of Liberal Arts for proposals for collaborative, interactive course work between their students and students in an equivalent class at a foreign institution. ${ }^{15}$ As a stimulus we offered a research bursary, whose amount was dependent on the length of the collaborative work. The scale was:

\footnotetext{
${ }^{11} \mathrm{~A}$ sine qua non introduction to COIL and a guide on developing COIL courses is http://www. ufic.ufl.edu/UAP/Forms/COIL_guide.pdf. Reed, 2016 reviews some of the programs with assessment data, while Esche, 2018 is a recent 'how-to' guide for faculty interested in developing COIL courses in their curriculum.

${ }^{12}$ Levinson \& Davidson, 2015 offer a review of 91 online cross-cultural pedagogical experiences.

${ }^{13}$ Examples of courses taught at different institutions may be found at http://coil.suny.edu/page/exa mples-coil-supported-courses).

${ }^{14} \mathrm{~A}$ full list, with discussion, of types of technology may be found at https://www.uwb.edu/glo balinitiatives/academic/coil-initiative/coil-resources.

${ }^{15}$ As an example of a COIL course, we envisioned a German 201 ("Intermediate German I") class at Texas A\&M being teamed with an intermediate German class at the University of Bristol. The English institution was desired, since both sets of students would be second-language learners; teaming with a German university would be intimating to the Americans who are not native speakers. Each class would meet separately and regularly throughout the semester, but students also work asynchronously online for about four weeks to collaboratively produce work and to reflect upon their own and their partners' cultural points of view. Teams of students, two to four per group, would work on pre-approved projects, such as the role of the media in political elections, immigration issues and the assimilation of immigrants, religious pluralism and religious fundamentalism, freedom of speech issues, and political elections. The students would use various communication technologies like Skype, Facetime, Facebook, and email, etc., to complete their projects, with the faculty members from each country coordinating and overseeing the coursework. The final project would be a PowerPoint presentation for presentation to both classes through Skype or some kind of wide-area data and interactive communications network.
} 
- $\$ 1,000$ for two weeks

- $\$ 1,500$ for three weeks

- $\$ 2,000$ for four weeks. ${ }^{16}$

Faculty were asked to complete a detailed proposal form in which they identified the course and their international collaborator. Certain questions required responses.

- "Describe the nature of the collaboration. What will the students do? How will you build the activities into the overall course content?"

- "Address issues of language, such as the primary language of most students in each class and their fluency level, and the language to be used in the collaborative project."

- "What electronic platforms will the students use? Will you need any assistance from the college's IT or instructional technology offices?"

- "How will you and your overseas collaborator assess the students' projects?"

The faculty member also agreed to administer the Global Perspective Inventory prior to and subsequent to the collaborative work, in order to assess whether students had improved their global awareness and perspective through the COIL experience.

For the pilot program, we chose two proposals: "Communication Leadership and Conflict Management," and "Senior Seminar in Classics." The Communication professor collaborated with a professor of law at the Law School of the University of South Wales. In this four-week collaboration, two to four Texas A\&M students teamed with two Australian students for the purpose of engaging in legal test cases that involved conflict and mediation. In each group, the Texas A\&M students role-played as CEOs; their Australian peers role-played as corporate lawyers who acted as their consultants or as their adversaries in arbitration and negotiations. The students corresponded with each other via multiple email conversations, and participated in asynchronous email negotiations as well as synchronous Skype mediations.

As a course requirement, students were required to turn in to the instructor their email threads and to write a reflection journal. The email threads demonstrated how often and in what way students interacted with one another and how the project was developed and completed. The journal captured students' critical thinking and their reflection on the similarities and the differences between American and Australian cultural perspectives on conflict management.

The second course we selected involved a classics professor working with a colleague in the Dipartimento di Filologia Classica at the Università degli Studi di Napoli Federico II. The Texas A\&M course was a seminar for graduating majors

\footnotetext{
${ }^{16} \mathrm{~A}$ special $\$ 3,000$ bursary was added if the faculty member incorporated a weeklong overseas field trip into the COIL course.
} 
in classics and focused on reader response/reception and the classical tradition, while the Italian students, who were in the masters program, were enrolled in a course on the history of traditional classical philology. The Texas A\&M students worked separately at the beginning of the course, writing research papers on the transformation of the classics through translation, transfer, and refiguration of literary and cultural traditions. Both sets of students used the theoretical models developed by the collaborative research group "Transformationen der Antike" at Humboldt-Universität zu Berlin (Heinze, Schirrmeister, \& Weitbrecht, 2013). Toward the end of the semester, the Neapolitan students joined and formed twoperson teams with the American students. For two weeks, the Italian students worked as peer reviewers of the drafts of the Americans' research papers through email, Facebook, Instagram, and Twitter. Common class discussions on the theory and methodology of reception theory were held through Skype. Language was not an issue, as most Italian university students are comfortable with English and both professors are fluent in Italian and English and so were available to help smooth over any linguistic bumps. Three weeks overall were spent on the collaborative efforts. In the end, the A\&M students gained an appreciation for what the Italian students can do with traditional models of philology, and the Italians were challenged by the innovativeness of new theoretical approaches to philological traditions.

\section{Discussion}

Did these courses succeed in providing students with a high-impact international experience? We address first the Australia/Texas A\&M online collaboration. The instructors reported that their students took the project very seriously. Through synchronous and asynchronous interactions, the Australian students role-playing as lawyers interacted extensively through their American team partners who, as said above, role-played as CEOs in conflict management scenarios. The course was the first time that Australian students had worked with American students, and vice versa. Both instructors and students considered the project accomplished course objectives and learning outcomes: the Australians learned the negotiation strategies and tactics that communications majors are taught, while the American students were introduced to the relationship between law and conflict management. Problems were encountered when it came to the time difference, which is 16 hours. This vast difference in time made real-time, face-to-face conferencing difficult.

The classics course produced terrific results. Both professors deemed the papers that emerged from the team projects to be of very high quality. Those papers that focused best on the applications of transformation theory to literature and culture from late antiquity to modern times were collected into a volume entitled Classics Transformed. This collection was recently published by Edizioni ETS, a highly reputable publishing house in Pisa, in the series, Testi e studi di cultura classica. Besides a preface and introduction, 14 papers appeared in the volume: seven from the Italian graduate students, seven by the American 
undergraduates (Abbamonte \& Kallendorf, 2018).

We have renewed the COIL program, not only to provide a unique international experience to any Liberal Arts student but also to improve the retention of our first-generation students. If colleges wish to improve graduation rates for first-time-in-college students who are first generation, purposeful and targeted programming in the initial year of study must be provided. Firstgeneration students are up to two times more likely to leave college during or after the first year (Choy, 2001; Ishitani, 2006). We are using as a model in this initiative the University of Texas at El Paso's COIL course for first-generation students. Dr. Effy George, Victoria University in Melbourne, Australia, and Irma Victoria Montelongo, University of Texas at El Pso, created this program, which is called the "VU-UTEP Global Learning Community." ${ }^{17}$ This project involves transforming first-year Liberal Arts core curriculum classes into a transnational class, entitled "Imagining Nations, Imagining Regions: The Making of Cultural Diversity in Australia and on the U.S.-Mexico Border." The class focuses on instilling in students an intercultural awareness and on eliminating cultural stereotypes that each set of students may have.

The dramatic increase in retention rates elicited by the VU-UTEP collaboration is intriguing. The attrition for students enrolled at the University of Texas El Paso has averaged one to two students, out of initial enrollments of 20. At Victoria University the average attrition rate is two to three students per 30 students. These retention rates are very atypical for the two institutions. Official certified retention rates for students at the university after the first year is $70 \%$. $^{18}$ But the students in the COIL program are retained at the rate 90 to $95 \%$. Such dramatic improvements in retention are a reason why Nassau Community College similarly have developed and implemented COIL classes as a way to increase its first-year retention. ${ }^{19}$

It is our intention to develop a COIL component for the Regents Scholars Initiative (RSI) program that we help oversee for the college. The RSI program is designed to assist first-generation college students in achieving their educational goals at Texas A\&M. Students receive up to $\$ 5,000$ per year for four years, in addition to other financial aid and scholarships. Each student is first generation, with an adjusted family gross income of less than $\$ 40,000$ per annum.

We coteach for the RSI students a class intended to provide the building blocks essential to success at Texas A\&M University. Topics include adjustment to college life, exploration of strategies to help manage time and to self-motivate, effective study habits, and test preparation. In the fall, the course is built around the acquisition of academic success skills and how to become engaged in campus life. In the spring, the first half of the course prepares the students for a weeklong trip to Costa Rica; there, students learn about ecotourism, archaeology, and

\footnotetext{
${ }^{17}$ Oberhelman was made aware of this fine program from the creators themselves at an October 2016 conference in Denver, Colorado: "AAC\&U Global Learning and the College Curriculum: Nurturing Student Efficacy in a Global World."

${ }^{18}$ Ten-year data may be found at https://www.utep.edu/student-affairs/financialaid/consumer-infor mation/Retention-Rates.pdf.

${ }^{19} \mathrm{An}$ in-depth report by Nassau Community College is available at the website, https://www.ncc. edu/middlestates/Enrollment_Plan_2018-21.pdf.
} 
history, and engage in a service project in an underserved community. The second half of the course is devoted to writing self-reflection papers and finalizing their journals. Students of color make up about $75 \%$ of the class, with the majority of students from inner-city schools and the Mexican border. About $70 \%$ of the students are Mexican-American.

The current first-year retention rate for our RSI students is $88 \%$. Since dramatic increases in retention rates are observable at other colleges when they create COIL opportunities for their first-generation students, we plan to create a COIL program for the RSI students. Retention of underrepresented and firstgeneration students is vital (Swail, Redd, \& Perna, 2003; Brundage, 2017), and so a COIL/ virtual component to the yearlong RSI course, with the potential to develop intercultural awareness and competencies of the students, nearly all of whom have never left the state of Texas, cannot be passed up. We have begun exploring a possible COIL course with the University of Sydney. This Australian university does not have a formal class for first-generation students, but it does have a "First in Family." 20 The initial proposal is to connect first-generation students at both institutions in ways by which they can discern similarities of being first generation, regardless of place, and yet also to learn about the differences.

\section{Conclusion}

International experiences play a very strong role in enhancing student success. They result in better retention rates, higher grade point averages, and significantly greater four-year, five-year, and six-year graduation rates. International experiences can assume many forms, from a weeklong field trip to an internship to a long-term study abroad program. Despite their knowledge of the benefits of international experiences, some students hesitate to participate. Costs are a big factor, especially for low-income students and students of underrepresented groups. First-generation students are reticent about leaving their families and support structure, and are reluctant to forgo income for study abroad. Students and parents alike have concerns about safety.

Courses with a collaborative online international learning component (COIL) offer a pedagogically viable alternative to physically leaving a country. At little to no cost, students can have an intensive, interactive experience with students of another culture. The pilot program developed at Texas A\&M demonstrates that students can have meaningful high-impact learning and acquire intercultural competencies through social media and interactive media platforms. Three weeks in, say, Athens or Barcelona can offer American students academic, cultural, and career benefits, but so can three weeks of collaborative online work with Catalan or Hellenic students.

\footnotetext{
${ }^{20}$ This is actually a national program in Australia: http://www.firstinfamily.com.au/. The University of Sydney has its own program, which is currently housed in its School of Economics; see the details at https://sydney.edu.au/arts/economics/fimf/index.shtml.
} 


\section{References}

Abbamonte, G., \& Kallendorf, C., (eds.) (2018). Classics Transformed. Testi e studi di cultura classica, 69. Edizioni ETS, Pisa.

Baker, D. Mc. A. (2014). The Effects of Terrorism on the Travel and Tourism Industry. International Journal of Religious Tourism and Pilgrimage, 2(1), article 9. doi:10.21427/D7VX3D. Retrieved from https://bit.ly/2H6ZFun.

Braskamp, L. A. (2014). Using the GPI for Evidence about Global Learning. Chicago: Global Perspective Institute, Inc.

Braskamp, L. A., Braskamp, D. C., \& Engberg, M. E. (2014). Global Perspective Inventory (GPI): Its Purpose Construction, Potential Uses, and Psychometric Characteristics. Chicago: Global Perspective Institute, Inc.

Brundage, I. (2017). Comparing Retention Factors of Minority Students: Comparison of Factors Contributing to the Retention of Minority Students at Two Different Types of Institutions: A Predominantly White Institution (PWI) and Hispanic Serving Institution (HSI) (Doctoral dissertation). Florida Gulf Coast University.

Choy, S. (2001). Students Whose Parents Did not Go to College: Postsecondary Access, Persistence and Attainment. NCES Rep. No. 2001-126. U.S. Department of Education, Washington, D.C.: National Center for Educational Statistics.

Deardorff, D. K. (2004). The Identification and Assessment of Intercultural Competence as a Student Outcome of Internationalization at Institutions of Higher Education in the United States (Doctoral dissertation). North Carolina State University.

Esche, M. (2018). Incorporating Collaborative Online International Learning (COIL) into study abroad courses: A training design. Capstone Collection, 3096. Retrieved from https://bit.ly/2AxOGo3.

Fukai, S. (2016). The Impact of Study Abroad on Post-graduation Job Search. Capstone Collection, 2870. Retrieved from https://bit.ly/2VtjWx8.

Gleye, P. (2017). Study abroad in a Time of Terror; U.S. Student Experiences in Brussels. Frontiers: The Interdisciplinary Journal of Study Abroad, 29(1), 15-27.

Goldrick-Rab, S. (2016). Paying the price: college costs, financial aid, and the betrayal of the American dream. Chicago: University of Chicago Press.

Goldrick-Rab, S., Richardson, J., \& Hernandez, A. (2017). Hungry and Homeless in College: Results from a National Study of Basic Needs Insecurity in Higher Education. Association of Community College Trustees. Retrieved from https://bit.ly/2D3QnLi.

Goldrick-Rab, S., Richardson, J., Schneider, J., Hernandez, A., \& Cady, C. (2018). Still Hungry and Homeless in College. Retrieved from https://bit.ly/2SECGrD.

Gordon, P., Patterson, T., \& Cherry, J. (2014). Increasing international study abroad rates for business students. Academy of Educational Leadership Journal, 18(3), 77-86.

Greenbaum, J. (2012). A Diversity Initiative in Global Education for First-generation Students. Capstone Collection, 2484. Retrieved from https://bit.ly/2VxNIAR.

Hamir, B. H. (2011). Go Abroad and Graduate On-time: Study Abroad Participation, Degree Completion, and Time-to-degree (Doctoral Dissertation). Lincoln: University of Nebraska.

Haupt, J., Ogden, A. C., \& Rubin, D. (2018). Toward a Common Research Model: Leveraging Education Abroad Participation to Enhance College Graduation Rates. Journal of Studies in International Education, 22(2), 91-107.

Heinze, A., Schirrmeister, A., \& Weitbrecht, J. eds. (2013). Antikes erzählen. Narrative Transformationenvon Antike in Mittelalter und Früher Neuzeit. De Gruyter, Berlin.

Houser, C., Brannstrom, C., Quiring, S. M., \& Lemmons, K. K. (2011). Study Abroad Field Trip Improves Test Performance through Engagement and New Social 
Networks. Journal of Geography in Higher Education, 35(4), 513-528.

Hunter, W. (2004). Knowledge, Skills, Attitudes, and Experiences Necessary to become Globally Competent (Doctoral dissertation). Lehigh University.

Institute for International Education. (2018). Open doors 2018. Retrieved from https://bit.ly/2OHebHu.

Ishitani, T.T. (2006). Studying Attrition and Degree Completion Behavior among FirstGeneration College Students in the United States. The Journal of Higher Education, 77(5), 861-885.

Levinson, N., \& Davidson, K. E. (2015). Linking Trajectories: On-line Learning and Intercultural Exchanges. International Journal for the Scholarship of Teaching and Learning, 9(2), article 3. Retrieved from https://doi.org/10.20429/ijsotl.2015.090203.

Malmgren, J., \& Galvin, J. (2008). Effects of Study Abroad Participation on Student Graduation Rates: A Study of Three Incoming Freshman Cohorts at the University of Minnesota, Twin Cities. NACADA Journal, 28(1), 29-42.

Maroto, M. E., Snelling, A., \& Linck, H. (2015). Food Insecurity among Community College Students: Prevalence and Association with Grade Point Average. Community College Journal of Research and Practice, 39(6), 515-526.

Mindi N. T., \& Phillips, J. C. (2012). Promoting College Retention in First-Generation College Students. In E. M. Vera (ed.), The Oxford Handbook of Prevention in Counseling Psychology. doi: 10.1093/oxfordhb/9780195396423.013.002.

Peet, S. H., Wooldridge, D., \& Sturm, M. (2015). Engaging Students in Learning: Lessons from Short-Term Study Abroad Experiences in Italy. Athens Journal of Education, 2(1) 2015, 23-36.

Reed, A. E. (2016). Student Participation in Coil Programs and its Impact on Study Abroad Enrollment. Capstone Collection, 2891. Retrieved from https://bit.ly/2Rz5145.

Simoes, A. R. M. (1996). Phonetics in Second Language Acquisition: An Acoustic Study of Fluency in Adult Learners of Spanish. Hispania, 79(1), 87-95.

Swail, W. S., Redd, K. E., \& Perna, L. W. (2003). Retaining Minority Students in Higher Education: A Framework for Success. ASHE-ERIC Higher Education Report, 30.2. Wiley Subscription Services, San Francisco.

Tinto, V. (1987). Leaving College: Rethinking the Causes and Cures of Student Attrition. Chicago: University of Chicago. 